of the oxidation products of ether. As yet the result has not been obtained with any pure compound.

Dr. N. Waterman, of Amsterdam, describes how carcinogenic agents inhibit the breakdown of cholesterol esters and possibly cause increased esterification of cholesterol in animals. The results indicate that agents which have a localized carcinogenic action may have a widespread effect in the animal. It is possible, but not certain, that general effects of this type may be an essential part of the careinogenic action. Prof. F. Vlès and Dr. A. Ugo show that if mice are injected with the fluorescent carcinogenic agent, 3:4-benzpyrene, the hair becomes fluorescent and the spectrum resembles that of the original hydrocarbon. Drs. J. G. Chalmers and P. R. Peacock show that the same compound is excreted as a fluorescent derivative in the bile. It is also excreted in some form in the urine, and thus animals excrete carcinogenic compounds by three routes, in skin fat, bile and urine, but in most cases the compound produces tumours only at the site of application and not along the paths of excretion.

Dr. Albert Fischer, of Copenhagen, reports on some interesting transplantation experiments. Tissue from salivary glands, liver, ovaries and mammary glands of young mice was grafted at a different site in the same animal from which the tissue was taken. After 10-14 days, the graft was inserted in a fresh place in the mouse, and this was repeated several times. In some cases the regrafted tissue developed into malignant tumours, showing that normal tissue may become malignant either by selection or by change in the character of the cells.

Among a number of papers on the nature of tumour viruses is one by Dr. A. Claude, of New York, showing that the virus of the Rous sarcoma No. 1 is destroyed by incubation with crystalline trypsin. Crystalline carboxypolypeptidase had no action on the virus. These results indicate that the Rous sarcoma agent is a protein. Other experimenters have found that the agent is not completely deposited on centrifuging at 15,000 R.P.M. but is completely deposited at 50,000 R.P.M.

Several communications deal with inherited predisposition and resistance to cancer. The results of Dr. Maud Slye, of Chicago, on mice breeding, indicate that types of cancer segregate as unit characters, and the incidence of malignancy at different sites can be explained by laws of heredity. Dr. N. DobrovolskaiaZavadskaia introduced radon tubes into the groins of female mice which normally had a high incidence of mammary carcinoma. The total incidence of cancer was not changed by such treatment, but one third of the tumours in the radon-treated mice were sarcomata instead of the usual mammary carcinomata.

One section of the volume deals with cancer diagnosis. Prof. P. Lamarque, of Montpellier, shows photographs of tissues made by microradiography. These are taken by placing a thin section of tissue on specially fine-grained photographic film and exposing the tissue and film to feebly penetrating $\mathrm{X}$-rays. Those parts of the tissue which contain heavy elements absorb the X-rays, and a photograph showing the distribution of heavy metals in the tissue is obtained. The results are similar to those obtained by microincineration, which shows the distribution of ash in tissues. Historadiography, however, has the advantage that the tissue is not treated so drastically as in incineration. It appears to the writer that a modification of this technique to determine the distribution of introduced radioactive elements such as radioactive phosphorus in tissues has possibilities.

The Second International Cancer Congress was well organized and the volume of "Reports" was published at the opening of the congress. The volume of communications contains many papers of value; it is unfortunate that they could not have been pub. lished immediately after the Congress. $\quad$ E. B.

\title{
Iron and Steel Works Developments
}

$\mathrm{I}^{\mathrm{N}}$ his presidential address to the Institution of Mechanical Engineers on October 21, Mr. David E. Roberts reviewed the changes which have taken place during the last fifty years in the basic industry of iron and steel making with which his experience has been primarily concerned. The twenty-five years preceding the Great War, when the world's annual output of steel increased from seven million to nearly seventy million tons, were marked by great activity in the development of improved processes of manufacture, and this period he regards as the one during which the greatest strides were made in the engineering side of the industry.

Sir Lowthian Bell, president of the Institution in 1884, established the ideal height for blast furnaces and, even to-day, few exceed 90 feet. In other respects, marked changes have been made. Hearths, from $11 \mathrm{ft}$. diameter, have been doubled in size while blowing pressure has increased from 5 to 25 pounds per square inch to ensure that the air will penetrate to the centre of the wider hearths. For blowing, Watt's beam engines with air cylinders 10-12 ft. in diameter are now replaced in Great Britain by turbines while, on the Continent, gas engines are largely used.
Raw materials are much more carefully selected and graded and the result is easier working of the furnace, with a saving of fuel and an increased output. Blast furnace gas, now cleansed most thoroughly, is actually cleaner than the normal atmosphere. It is used for driving gas engines or, when mixed with the richer coke oven gas, for heating and smelting operations. In the Ruhr area, with its very numerous blast furnaces and coke ovens, the whole of the works are connected to a huge pipe grid and every cubic foot of gas generated is effectively used-there is no waste such as is sometimes seen in Great Britain. Steel manufacture has also developed greatly. The Bessemer converter has returned to favour for the production of commercial steel-on the Continent it has been practically the only method of making common steel. The open-hearth process is the British mainstay and these furnaces have increased from 20 to 100 tons capacity, while some tilting furnaces of 250 tons capacity are in use. Much mechanical equipment is installed in the melting shop to increase the speed of operation and to ease the labour and exertion involved in handling vast masses of molten metal. 
In the rolling shops the simple type of reversing mill has given place to massive machines rapid in operation and provided with lifting tables and other manipulating devices. The absence of noise is remarkable when it is realized that at each reversal some 150 tons of machinery is brought to rest and re-started. An example of the adaptation of new materials to attain improved results is the use of fabric bearings to carry the heavy rolls. One of the most recent developments is the rolling of sheets by what is known as a 'strip mill'-composed of a continuous series of roll stands in tandem arrangement. Twenty of these huge mills are in operation in the United States and one is being installed in this country. The early attempts to roll sheets in a continuous mill were frustrated by the difficulty of ensuring that successive pairs of rolls were of exactly corresponding contour and consequent troubles with "ripples" ensued. The Ashland plant in 1922 demonstrated the correct principles and the American strip mills are now stated to have an annual capacity of 12 to 13 million tons. The graduation of the thickness of the sheet throughout such a mill is vitally important and automatic recording devices have to be employed so that variations can be shown on a much magnified scale.

\section{Science News a Century Ago}

\section{Education in the Metropolis}

THE Statistical Society on November 19, 1838 , held its first meeting of the session, the first communication being the third report of the Society's Committee appointed to inquire into the state of education in the Metropolis. This report contained a description of the schools in the parishes of St. George, St. James and St. Anne, Westminster. The area of these districts was 1,310 acres and the population, according to the census of $1831,110,862$. It was estimated that there were 21,502 children between the ages of five and fifteen years, and of these less than one third received instruction in a school. There were four kinds of private schools-dance schools, common day schools, middle and superior schools-besides charity and infant schools. The Committee had found the teaching imperfect, the surroundings often cheerless and there was a notable absence of a good supply of literature. Inquiries had been made at some five hundred houses and the members of the Committee had been met with courtesy.

\section{Blasting by Electricity}

AT a meeting of the London Electrical Society on November 20, 1838, a paper was read by Martyn Roberts entitled "On the Use of Galvanism in Blasting Rocks". A report of the paper appeared in Sturgeon's Annals of Electricity, 3, p. 423. The author described experiments, which had been attended with perfect success, made on granite rocks in the neighbourhood of Penzance, Cornwall. His method was to bore a hole $2 \mathrm{ft}$. deep in the granite and place 3 in. of gunpowder in it. A wad of oakum was then driven in 9 in. from the top of the hole, leaving 12 in. of air between the wad and the powder. The upper part of the hole was filled with sand, "a convenience being allowed for placing a thin iron wire in connexion with the powder, which wire became red hot, and consequently exploded the charge, when connected with the voltaic battery".

\section{Interior of the Earth}

ON November 22, 1838, W. Hopkins read a paper to the Royal Society entitled "On the State of the Interior of the Earth". The object of the paper was to inquire into the modes in which the 'refrigeration' of the earth may have taken place, on the hypothesis that its entire mass was originally in a fluid state; a hypothesis which was at first founded on astronomical considerations and was corroborated by the discoveries of modern geology exhibiting the apparent injection from below of large masses of unstratified rocks, through the fissures of sedimentary strata. In the course of his discussion, Hopkins said that the internal mass of the earth may consist of matter still in a state of fusion, or the earth may consist of an external shell and a solid central nucleus with an intermediate stratum of matter in a state of fusion, or the earth may be solid from surface to centre.

The author of this paper, William Hopkins, was borm on February 2, 1793, and died on October 13, 1866. He began life as a farmer but at the age of twenty-nine years entered Peterhouse, Cambridge, and graduated as seventh Wrangler five years later. Settling at Cambridge as a tutor, he had among his pupils Stokes, Kelvin, Tait, Clerk Maxwell and Todhunter. It was through Sedgwick that he acquired a taste for geology. In 1850 he was awarded the Wollaston Medal for his application of mathematical physics to geology, and in the following year he served as president of the Geological Society. In 1853 he was president of the British Association. After his death the Cambridge Philosophical Society founded a prize in his honour.

\section{University Events}

Cambridge.-A. L. Percival, of Jesus College, and H. G. Rhoden, of St. John's College, have been appointed University demonstrators in engineering, and A. M. Barrett, of Pembroke College, has been appointed University demonstrator in pathology,

J. R. F. Jeffreys, of Downing College, has been elected to an Isaac Newton studentship.

The degree of Sc.D. has been conferred on $\mathbf{F}$. Yates, of St. John's College.

T. P. Hughes, Rhondda research student, 1935-37, of Gonville and Caius College, has been elected into an unofficial Drosier fellowship for research in chemistry.

The following new appointments have been made in connexion with the Cambridge Philosophical Soriety : Vice-President, Prof. F. J. M. Stratton; New Members of the Council, Dr. E. C. Bullard, Dr. E. J. Maskell and Dr. F. C. Phillips.

SHEFFIELD.-The following appointments have recently been made: Dr. G. K. 'T. Conn, assistant lecturer in physics; W. J. Lytle, honorary lecturer in surgical pathology ; Dr. H. E. Harding, honorary lecturer in medical pathology; J. Hughes, honorary demonstrator in anatomy; F. G. West-Oram, at present junior research assistant, as assistant lecturer in glass technology. 